\title{
TRANSICIÓN E INSTALACIÓN DEMOCRÁTICA EN CHILE CONTEMPORÁNEO
}

\author{
Azun Candina Polomer
}




\section{AZUN CANDINA POLOMER}

Doctora en Historia, Profesora Asociada del Departamento de Ciencias Históricas e investigadora asociada del Archivo Central Andrés Bello de la Universidad de Chile. Sus áreas de trabajo son los estudios de memoria y la construcción de identidades sociales en la historia reciente de Chile y América Latina. 


\section{TRANSICIÓN E INSTALACIÓN DEMOCRÁTICA EN CHILE CONTEMPORÁNEO}

\section{UN PERIODO EN MODO DE PREGUNTA}

La convocatoria a escribir este texto requirió referirse a la transición como periodo histórico. Ello despierta cierta ansiedad a quien se desempeñe en este oficio, no necesariamente por la tentación bizantina de perderse en ese bosque semánticodisciplinario acerca de qué podríamos definir como un-periodo-histórico, sino porque como tal, al menos debería tener, para que hablemos de él aunque no hagamos esa reflexión conceptual a profundidad, un alegado comienzo y un alegado final. A las y los chilenos -incluyendo historiadores- nos cuesta definir cuándo comenzó y terminó nuestra transición a la democracia. No ocurre así con otros procesos del siglo XX: no suele haber dudas, por ejemplo, respecto a que la larga permanencia del latifundio tradicional sufrió una crisis terminal a partir de la Reforma Agraria de fines de los '60, o que la dictadura cívico-militar comenzó un día 11 de septiembre de 1973. Algo hay allí, un ruido se instala cuando -como ocurrió en la década de 1990 y sigue ocurriendo hasta hoy- nos preguntamos si nuestra transición a la democracia comenzó en 1988 o en 1990 y terminó en 1994, o el año 2000, o tal vez aún está siendo.

Nos hemos acostumbrado a ello, hemos asumido esa rareza y vale la pena preguntarse por qué. Una transición política es -o se esperaría que fuera- justamente un tránsito, una especie de viaje de un tipo de gobierno a otro, y en el caso que tratamos, de una dictadura a una democracia. Si la transición ya estaba "hecha" o no fue uno de los temas de debate de la academia, la política y la sociedad civil chilena en las décadas de 1990 y 2000: hubo quienes la declararon como exitosa y terminada -es decir, que afirmaron que ya estábamos viviendo indiscutiblemente en democracia-, y hubo quienes plantearon serias dudas al respecto o incluso llegaron a negar que esa transición hubiese ocurrido. Para ciertos grupos - particularmente los que continuaron proyectos de insurrección o lucha armada tras 1990-, bajo ningún punto de vista la dictadura había terminado: Augusto Pinochet había dejado la presidencia, pero era indiscutiblemente poderoso, la Carta Constitucional de 1980 seguía vigente y la derecha no había sido ni lejanamente derrotada. Otros sectores menos radicales, pero de todas maneras críticos, aceptaron que efectivamente hubo una transición a la democracia, pero que esta era incompleta y continuaba siendo, por lo tanto, un proceso pendiente. 
Los periodos históricos, por lo demás, no son solo fechas de gobiernos o de cambios de gobiernos, ni el día y año en que algo ocurrió o dejó de ocurrir. Son también una sensibilidad, un tono de la vida cotidiana e institucional, una percepción acerca de lo que está ocurriendo y de las expectativas del futuro. "Aprende a portarte bien/en un país donde la delación será una virtud”, escribió el poeta Jorge Teillier en dictadura y sobre la dictadura ${ }^{1}$, y quizás hay pocas palabras que resuman mejor ese ambiente cotidiano y permanente de miedo, desconfianza, de poder omnímodo de unos y fragilidad de otros. No podemos, de tal manera, confiar solo en las fechas o los eventos públicos para definir un periodo histórico: Augusto Pinochet desprendiéndose de la banda presidencial en 1990 para entregársela a Patricio Aylwin constituye un acontecimiento formal y público relevante, pero qué significó en términos de la sociedad chilena -si fue el hito de algo o de nada- es una pregunta mucho más compleja.

Este texto se articula desde esa perspectiva. Si hubo una transición de dictadura a democracia en Chile, si existió, efectivamente, un periodo identificable en sí mismo, con su propio tono, diferente a lo que hubo antes y a lo que hubo (quizás) después, es una pregunta que debe tratarse desde algunos fenómenos y fechas significativas, ciertamente, pero también es una interrogación sobre una sensibilidad, un estado de ánimo y unas expectativas en armonía o desencontradas, según el caso.

Proponemos aquí que la transición a la democracia como periodo histórico sí existió y que tuvo características propias. Proponemos también que no ocurrió tras el plebiscito de 1988 o la elección presidencial de 1989, ni con la asunción como presidente de Patricio Aylwin en 1990. Tampoco terminó en 1994, con el segundo gobierno de la Concertación de Partidos por la Democracia, o en 1998, con la detención del general Pinochet en Londres. Nuestra hipótesis es que lo que vivimos en esa década de 1990 fue una instalación democrática, porque la transición a la democracia, como periodo histórico, ya había ocurrido. Esa verdadera transición se trató, en el caso chileno, de una negociación entre el gobierno dictatorial y un sector de la oposición - en el contexto de un amplio debate y lucha social- para terminar con dicho gobierno de facto e instalar una forma específica de democracia. Dicho proceso se inició en 1983 y terminó en 1989.

\section{EL TIEMPO CRISPADO}

1983 fue un annus horribilis para la dictadura chilena. Cumplía una década en el poder, pero el horno no estaba para bollos. La crisis económica que comenzó

1. TEILLIER, Jorge, "Sin Señal de Vida", en Para un Pueblo Fantasma, Santiago, Tajamar Editores, 2009 (primera edición, 1985), p.155. 
en 1982, para 1983 mostraba consecuencias sociales brutales: altísima cesantía, jornadas de protesta y "cacerolazos" (¡Lucia, Lucía, la olla está vacía.) en las principales ciudades. Las cifras económicas eran demoledoras: el PGB cayó en un 14,4\%, la inflación ascendió sobre un $20 \%$, se produjo una ola de quiebras de empresas e intervenciones de bancos, la cesantía llegó a un 19,6\% en 1982 y un 26,4\% en 1983, y un cálculo aproximado llegó a advertir que en los sectores poblacionales, y especialmente entre los jóvenes, esa cesantía alcanzó a un $50 \%{ }^{2}$.

Algo se quebró ese año 1983. La grandes manifestaciones para celebrar la gesta heroica del 11 de septiembre de 1973, para saludar al general Pinochet el día de su cumpleaños o para recibir a Lucía Hiriart cuando visitaba hospitales o centros de madres $^{3}$ no desaparecieron, pero se empequeñecieron y ralearon paulatinamente. La seguridad de haber derrotado al marxismo, de tener al país bajo control y de haber construido una nueva institucionalidad seguía allí, pero recorrida por un aire de peligro y de precariedad. Los opositores, que durante esos diez años de dictadura habían sobrevivido duramente a la represión y la censura sistemáticas, parecieron multiplicarse. Ya no eran solamente los heroicos activistas de la Vicaría de la Solidaridad, ni los familiares de los detenidos desaparecidos y ejecutados políticos los que alzaban la vOz, ni los estudiantes universitarios que se atrevían a desafiar el cerco de censura. Tampoco se trataba ya de este u otro ex upeliento que murmuraba entre dientes sus reclamos contra "el caballero" o "el régimen", eufemismos que hablan por sí mismos de un silencio político que solo admitía esos murmullos de rabia o de dolor en los márgenes de un país que se promocionaba como ordenado y exitoso. Hasta ese año, la mayoría de la población daba la impresión de estar más preocupada de los chismes que rodeaban al Festival de Viña del Mar (música-juntoal-mar), los chistes del Jappening con Ja y los largos Sábados Gigantes de Don Francisco que de la memoria de Salvador Allende y Víctor Jara, o de la suerte del millón de exiliados repartidos por el planeta. Desde 1983, no. Desde 1983 y en los años siguientes algo se crispó en las calles, los barrios, las universidades, los liceos y las industrias chilenas. El discurso de que sí, se vivía en dictadura, pero que de todas maneras se estaba más o menos bien era insostenible en un país donde se devaluaba la moneda, los cesantes lloraban de desesperación y entre los pobres, que nunca habían dejado de ser pobres, había literalmente hambre. La grieta de la Casa Usher empezó a crecer.

2. CORREA, Sofía, FIGUEROA, Consuelo, JOCELYN HOLT, Alfredo, ROLLE, Claudio, VICUÑA, Manuel, Historia del siglo XX chileno, Santiago de Chile, Editorial Sudamericana, 2001, p.327.

3. CANDINA, Azun, "El día interminable: memoria e instalación del 11 de septiembre en Chile", en Elizabeth Jelin, editora, Las fechas in-felices, Buenos Aires, Editorial Siglo XXI, 2002, p.9-52. 
No fue una coincidencia, por lo tanto, que empezaran a sentirse ciertos aires de apertura y de discusión entre gobierno y opositores. Cada grupo tenía, por cierto, sus fortalezas y debilidades. El gobierno contaba con las Fuerzas Armadas y las policías, con el mismo hecho de estar en el poder y con una capacidad de censura y represión organizada y eficiente, además de un apoyo claro de la derecha y de buena parte del empresariado. Sin embargo, su imagen internacional era muy negativa, estaba enfrentando esa mencionada y creciente protesta social y lidiaba con una crisis económica de proporciones. La oposición, por otra parte, era el concurrente débil en términos de poder de fuego y acceso a la prensa y el poder formal, pero contaba con una alta legitimidad y apoyo fuera del país y tenía a su favor a las cada vez más visibles organizaciones estudiantiles, populares, sindicales y sociales contrarias al autoritarismo. Como no había tenido ninguna participación en las decisiones económicas del gobierno, podía indicarlo sin restricciones como el gran culpable de la crisis económica y los altos índices de pobreza y cesantía que afectaban al país.

Consideramos, por lo tanto, que la transición comenzó en dicho año por dos motivos: fue el inicio de esa mencionada negociación entre el gobierno dictatorial y el sector moderado de la oposición política para definir qué democracia se instalaría en Chile, y fue también el año en que la mayoría de los chilenos se comportaron y se vieron en transición, es decir, fueron espectadores o participantes -en mayor o menor grado- de ese cambio de cotidiano. En marzo de 1983 una coalición de la oposición liderada por el Partido Demócrata Cristiano y el Partido Radical suscribió un manifiesto democrático donde se pedía la renuncia del general Pinochet a la presidencia. Sería el primer documento conjunto de lo que se convertiría en la Alianza Democrática (AD), fundada el 6 de agosto de ese mismo año (antecedente directo de la Concertación de Partidos por la Democracia) y que entre 1983 y 1987 lideraría la oposición de centro-izquierda al gobierno. El 25 de agosto, un actor central (por entonces) de la política chilena se sumó a esos esfuerzos; el Cardenal Juan Francisco Fresno apoyó la firma del Acuerdo Nacional para la Transición a la Plena Democracia planteado por la AD. Por su parte, el gobierno nombró a Sergio Onofre Jarpa - un civil y un antiguo político de la derecha- como ministro del Interior y se le dio la tarea de negociar con esa oposición de centro-izquierda.

Ambos grupos se movían en terrenos difíciles al interior de sus propios campos: el gobierno tenía sectores refractarios a dichas negociaciones, dispuestos a defender la obra de esos diez años a ultranza y no transar en nada con "los marxistas", mientras que en la oposición las cosas no iban mejor: los grupos más a la izquierda, como el Movimiento Democrático Popular (MDP), estaban por derrocar al dictador sin concesiones. Sin embargo, los factores ya mencionados -la crisis económica, el aumento indiscutido de las protestas sociales, el fortalecimiento de los sectores opositores, la mala imagen internacional del gobierno, el hecho de que ya llevaba 
diez años en el poder y de que dentro de él no todos estaban de acuerdo con el concepto de "metas, no plazos" anunciado por Pinochet en $1977^{4}$ - probablemente lograron que los sectores gobiernistas que estaban por negociar con la oposición adquirieran mayor fuerza. Mirando dicho proceso en perspectiva, los dados ya estaban lanzados.

Por supuesto, fue un camino dificultoso, con avances truncos, esperanzas rotas, peleas y retrocesos frecuentes. El general Pinochet, autodenominado Presidente de la República desde 1980, no sentía simpatía por esos acercamientos y varias veces los hizo tambalear con sus declaraciones públicas de seguir "en guerra" y su notoria aspiración de perpetuarse en el poder ${ }^{5}$. Sergio Onofre Jarpa renunció en 1985 ante la oposición de Pinochet a continuar con el proceso de apertura y negarse a considerar siquiera renunciar a su cargo y modificar la Constitución de 1980. La dura represión a las organizaciones sindicales, gremiales y políticas tampoco ayudaba al proceso. Por otra parte, la decisión del Partido Comunista de asumir "todas las formas de lucha” y la creación del Frente Patriótico Manuel Rodríguez (FPMR), precisamente en 1983, contradecía a una oposición que intentaba demostrar su vocación por la paz y un retorno sin violencia a la democracia: su llamado a la sublevación popular y al derrocamiento armado del dictador ${ }^{6}$ no dejaban dudas sobre su muy escaso interés en salidas pactadas.

Se trató, entonces, de un periodo político extraño y dual, por llamarlo de alguna manera. En su verbo público, en las manifestaciones, los actos a favor o en contra del gobierno y en las declaraciones en la prensa nacional e internacional, el gobierno y la oposición -aun sus sectores no marxistas y lejanos a la lucha armada- mantuvieron respectivamente una actitud beligerante y triunfalista. $\mathrm{La} \mathrm{AD}$ clamaba por la renuncia de Pinochet y el llamado a elecciones libres, y anunciaba cada año -y a veces hasta cada mes- que la caída del dictador era inminente. El gobierno declaraba una y otra vez que no se movería ni un ápice de la ruta diseñada en la Constitución Política de 1980 y que su lucha anti-marxista y contra la demagogia de "los políticos" seguía intacta. Sin embargo, las negociaciones y los debates continuaron al interior de cada trinchera y entre esos grupos aparentemente irreconciliables.

4. Nos referimos aquí al conocido Discurso de Chacarillas de Augusto Pinochet, pronunciado en julio de 1977 en el acto de conmemoración de la muerte de los Héroes de La Concepción durante la Guerra del Salitre (1879-1883). La principal disidencia enfrentada (y superada) por el gobierno fue la del general de la Fuerza Aérea Gustavo Leigh, quien estaba por entregar el gobierno a los civiles y fue retirado de la Junta Militar en 1978.

5. Para un relato de los avatares internos de dicho juego, ver en particular CAVALLO, Ascanio, Los Hombres de la Transición, Editorial Andrés Bello, 1992, passim.

6. Ver Primer Manifiesto Rodriguista, noviembre de 1984, en http://www.fpmr.cl/index. php/2016-11-11-18-07-51/2016-11-11-18-10-50. Consultado el 2 de noviembre de 2018. 
Esa danza extraña - de pelea frontal en lo público y de cavilación privadacontinuó y se intensificó en la medida en que ninguna de las dos partes pudo neutralizar o destruir a su adversario. Si en lo peor de la crisis económica y si en lo más duro de las jornadas de protesta hubo sectores de la oposición que confiaron en que el gobierno dictatorial no resistiría el embate, el paso de los meses mostró que ello no estaba ocurriendo y que probablemente no iba a ocurrir. El gobierno perdió y siguió perdiendo adeptos, a sus manifestaciones públicas iba cada vez menos gente, pero su núcleo no se despedazó: las Fuerzas Armadas no se quebraron en disidencias internas y la derecha política y económica continuó asegurando su apoyo. Junto a ello y en una decisión de la mayor importancia, insistieron en que el recorrido político marcado por la Constitución de 1980 debía cumplirse.

Vale la pena recordar ese texto constitucional en su versión original y la importancia que tuvo en la época. La legitimidad y el respeto a la Carta de 1980 eran un punto central en los debates entre gobierno y oposición. Aprobada en una votación vergonzosa, sin registros electorales y sin ninguna garantía de transparencia y legalidad, la oposición la consideraba inaceptable: había entregado al general Pinochet otros ocho años más en la presidencia de la República (de hecho, lo nombró presidente), le dio la posibilidad de reelegirse por otros ocho años en 1988 y establecía en su ominoso artículo $8^{\circ}$ que "todo acto de persona o grupo destinado a propagar doctrinas que atenten contra la familia, propugnen la violencia o una concepción de la sociedad, del Estado o del orden jurídico, de carácter totalitario o fundada en la lucha de clases, es ilícito y contrario al ordenamiento institucional de la República"7; es decir, declaraba ilegal a todo partido y movimiento marxista o de izquierda. Aun si alguna vez los militares abandonaban la presidencia de la República y los ministerios, y se restablecían las elecciones y el funcionamiento del Congreso, se trataría de una "democracia protegida", donde una parte relevante del Senado estaría compuesta por miembros vitalicios designados por la dictadura y los comandantes en jefe no podrían ser removidos de sus cargos.

Por supuesto, la Carta de 1980 había sido diseñada y aprobada en un periodo en que la dictadura cívico-militar se encontraba en la cumbre de su poder. Entre 1973 y 1983, al interior del país la oposición había contado con personas, grupos y organizaciones heroicas y dispuestas a dedicar e incluso rendir la vida en la lucha antidictatorial, pero eran cuantitativamente muy pocos comparados con el total de la población y su capacidad de comunicarse con esa mayoría de chilenos era

7. Ver texto original en versión digital en el sitio de la Biblioteca de Congreso de Chile, https:// www.bcn.cl/historiapolitica/constituciones/detalle_constitucion?handle $=10221.1 / 60446$, visitado el 6 de noviembre de 2018. 
extremadamente baja: los únicos medios de comunicación masivos eran la televisión abierta, la prensa impresa y la radio, y eran controlados casi completamente por el gobierno. Durante esa primera década en el poder la dictadura efectivamente pudo desarrollar sus planes políticos y económicos sin contrapeso, en una situación inédita en la política nacional.

Pero -y de nuevo- 1983 no era 1980. Ese año y durante los dos o tres siguientes, Chile ya no fue un país donde no se movía una hoja sin que el general lo supiera (y la cortara, quemara o deportara con eficacia). En un fenómeno de influencia mutua, probablemente, las jornadas de protesta nacional fueron acompañadas por un florecimiento de las revistas y periódicos de oposición y por una presencia cada vez más visible de los opositores en la arena pública. Solo por mencionar uno de muchos hechos significativos, el asesinato del sacerdote André Jarlan en La Victoria, en 1984, provocó la indignación de sus pobladores y una marcha al centro de la ciudad, donde el grito de "iya no tenemos miedo!" resonó en la ciudad primada, la de ministerios, paseos y oficinas importantes, donde esos otros santiaguinos pobres y marginados no tenían un lugar; la conocida fotografía de Álvaro Hoppe muestra a esos manifestantes de brazos entrelazados para formar un solo bloque y evitar que la policía los dispersara, subiendo por uno de los pasos subterráneos del centro de Santiago, gritando su pena, su rabia y su desafío a un poder que hasta hacía poco se consideraba muy seguro de sí mismo.

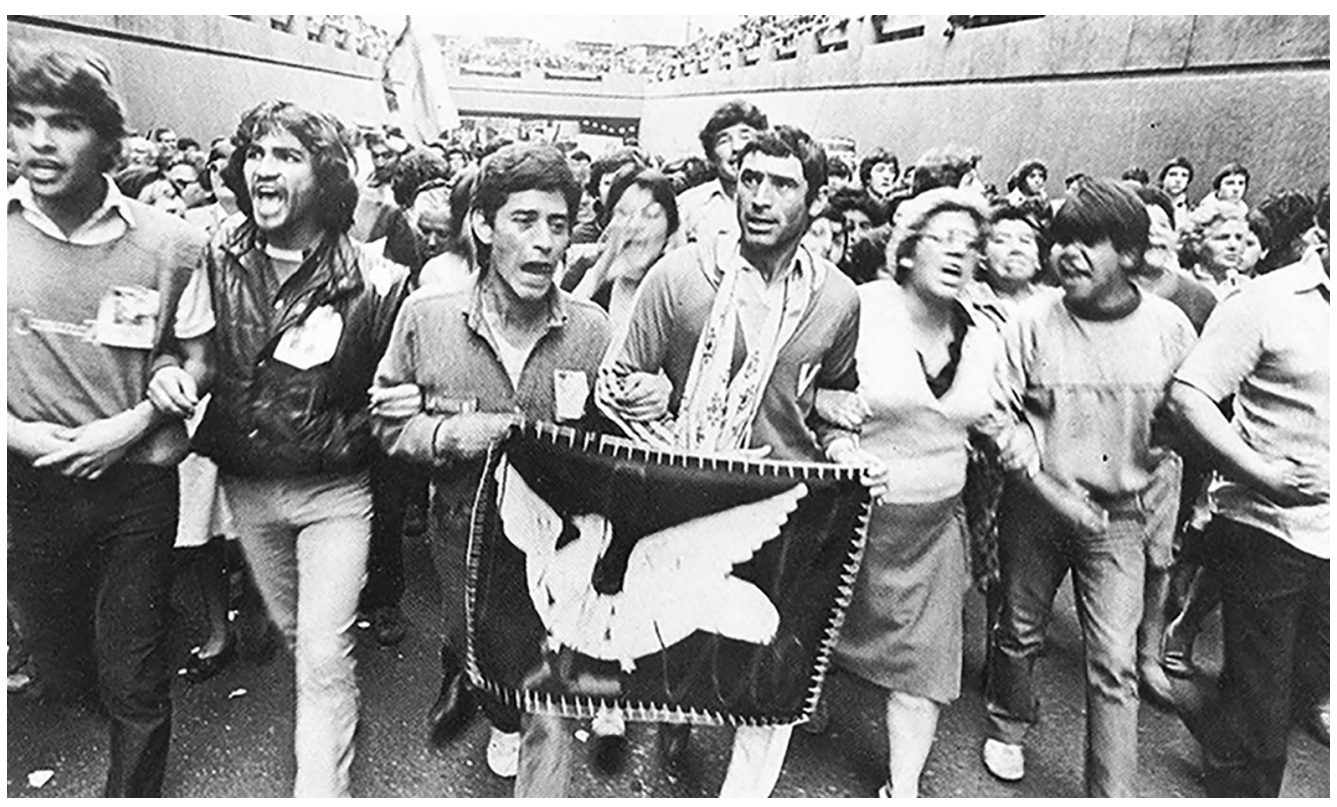

Álvaro Hoppe, septiembre de 1984. Funeral del asesinado sacerdote francés André Jarlan. Pobladores de La Victoria. 
Medios de prensa como Cauce, APSI, La Bicicleta y Fortín Mapocho, junto a las radioemisoras de oposición criticaron y se burlaron abiertamente del gobierno y cumplieron -bajo una represión que no cejó pero que ya no era capaz de acallarlosla labor de difundir las acciones y debates de los grupos opositores, informar sin censura sobre la situación internacional y más aun: hicieron circular un verbo, un arte y una estética prohibidas en lo público durante una década ${ }^{8}$ la memoria de la Unidad Popular y de su caída reaparecía una y otra vez en imágenes, música y relatos, y también la producción artística y literaria de los ' 80 en sellos, editoriales y revistas alternativas que no ocultaban demasiado su rechazo a la producción "apolítica" y "de sana entretención" de la dictadura, y su visión crítica de la sociedad chilena.

En dicho sentido, vale la pena recordar que la transición también fue un fenómeno cultural y expresivo en que se mezcló el dolor por la muerte violenta de la Unidad Popular y de sus sueños, la rabia contra el despotismo, la producción artística e intelectual propia de ese Chile en dictadura y el miedo y las dudas hacia el futuro. Patricia Politzer, en su excelente libro de testimonios llamado precisamente Miedo en Chile ${ }^{9}$, captó con maestría a esos chilenos y chilenas de diferentes edades, clases sociales e ideas políticas, que temían ora al retorno del marxismo o a la violencia dictatorial, a la cesantía, a la pobreza, a la persecución o al castigo. De una forma u otra, dichos testimonios de esos años ' 80 reflejan bien que el ambiente a la vez de inseguridad, de lucha y de negociación no se registraba solamente en las élites políticas. Una sociedad quebrada, herida y dividida también reflexionaba, pensaba el futuro y se preguntaba cuál sería la salida posible a una década de autoritarismo y de excepción, y un posible retorno a un régimen democrático. Entre las dudas, las declaraciones tajantes, la crisis económica y las grietas, esa propuesta fue tomando forma.

Es posible afirmar que un año decisivo al respecto fue 1986. Usamos el término "decisivo" intencionadamente: la oposición había fijado como meta ese año como el último en que soportarían al general Pinochet y la Junta de Gobierno en el poder: 1986 fue bautizado el año decisivo en ese sentido. Y acaso lo fue, pero de una manera diferente a la esperada. Para 1986, la crisis económica de 1982-

8. El material disponible sobre la producción artística, cultural y periodística de la oposición en dictadura afortunadamente ha crecido en los últimos años. De esos estudios y fuentes se pueden mencionar dos, de muchas y valiosas referencias: el archivo digital del periódico Fortín Mapocho, disponible en http://www.archivofortinmapocho.cl, y particularmente la historia oral de la ACU (Agrupación Cultural Universitaria), que refleja bien el tono de la época del que se quiere hablar en estas páginas, en MUÑOZ, Víctor, ACU rescatando el asombro: historia de la Agrupación Cultural Universitaria, Santiago, Libros La Calabaza del Diablo, 2006.

9. POLITZER, Patricia, Miedo en Chile, Santiago de Chile, CESOC, 1985. 
83 aún no estaba superada, pero sus efectos empezaban a amainar, las llamadas jornadas de protesta también habían disminuido su intensidad y el FPMR falló en su intento de tiranicidio el 7 de septiembre de 1986, en un atentado que costó la vida a cinco escoltas presidenciales y dejó a once uniformados heridos, pero donde el automóvil en que viajaba el general Pinochet logró escapar. El tiranicidio fallido y otras acciones y estrategias de violencia armada distanciaron definitivamente a la oposición moderada y que optaba por un camino pacífico -reunida en la Alianza Democrática- de los partidos y grupos que estaban por la sublevación popular, agrupados en el Movimiento Democrático Popular.

El horizonte deseado de la izquierda, es decir, el que tenía como meta el derrocamiento del dictador, la derogación de la Carta Constitucional de 1980, la salida de las Fuerzas Armadas del poder político y el juicio y castigo a los culpables de la represión, se había debilitado claramente para ese momento: una suerte de continuación del interrumpido proyecto de la Unidad Popular, por ejemplo, o de sublevación popular que desde las calles terminara con el gobierno de facto e iniciara una nueva democracia popular y sin los militares y la derecha, se convirtió en una posición claramente minoritaria. 1986, quizás por haber sido el año en que supuestamente se derrocaba a la dictadura y el año en que no ocurrió, se convirtió retomando la idea previa- en el año decisivo, el último en que esa esperanza pareció alcanzable. Significativamente, en 1987 el Partido Comunista decidió sumarse, junto a la mayoría de los partidos de oposición, a votar No en el plebiscito que la dictadura cívico-militar había planificado en la Carta Constitucional de 1980 y que se llevaría a cabo en 1988: uno de los partidos más perseguidos y golpeados por la represión, y que había sido protagonista de la opción por derrocar y por no transar con la dictadura, aceptó las reglas del juego. Fue, quizás, la señal política más clara de que en la larga danza de claroscuros de esos años, las fuerzas de oposición no lograron que el gobierno abandonara la ruta trazada en la Constitución de 1980, pero sí consiguieron que dicho plebiscito se realizara con registros electorales dignos de dicho nombre, con apoderados de mesa que vigilarían la limpieza del proceso y con una campaña donde por primera vez en quince años la oposición tuvo una franja de propaganda en la televisión abierta y en cadena nacional, no intervenida ni censurada por el gobierno.

En términos mediáticos, el contenido y el éxito de esa franja televisiva del No son una buena muestra de un proceso de transición que estaba llegando a su fin. Criticada por los sectores más radicales por su mesura, su tono festivo y su constante llamado a la paz y a la reconciliación, proponemos que dicha propaganda no ocultó sino que quiso visibilizar y promocionar esa transición pactada con el gobierno. Directa e indirectamente, a través de las imágenes y las palabras que llamaban "sin odio, sin miedo y sin violencia" a votar No, que mostraban a los chilenos abrazándose tras un 
largo tiempo de oscuridad y que adoptó como símbolo un arcoíris, la franja buscó, por supuesto, neutralizar el discurso anti izquierdista y tremendista del gobierno (si ganaba el No, el país se hundiría en el caos), pero fue más allá: explicó que el regreso de la democracia se trataría casi de un trámite administrativo, de una reforma buena pero menor a una estructura de poder y de gobierno y a una vida cotidiana que no cambiarían demasiado, y que el gran cambio sería, precisamente, que lo que ya existía sería aun mejor: el tesoro al final del arcoíris, ciertamente.

La estrategia de aceptar el plebiscito de 1988 funcionó a nivel social y ciudadano, y más allá de la alternativa que finalmente ganó. Los sectores pinochetistas se aprestaron masivamente a defender la obra del que consideraban su gobierno y los que estaban por el derrocamiento de la dictadura y que se negaron a inscribirse en los nuevos registros electorales y a participar en la votación fueron una minoría. Vale la pena observar el siguiente cuadro sobre la participación a nivel nacional en el plebiscito de 1988:

\begin{tabular}{|l|l|l|l|l|l|l|}
\hline Año & $\begin{array}{l}\text { Población } \\
\text { en edad de } \\
\text { votar (PEV) }\end{array}$ & $\begin{array}{l}\text { Inscritos en } \\
\text { los registros } \\
\text { electorales }\end{array}$ & $\begin{array}{l}\text { Votantes } \\
\text { plebiscito } \\
\mathbf{5 - 1 0 - 1 9 8 8}\end{array}$ & $\begin{array}{l}\text { \% de } \\
\text { inscritos } \\
\text { en relación } \\
\text { a PEV }\end{array}$ & $\begin{array}{l}\text { \% de } \\
\text { votantes } \\
\text { en relación } \\
\text { a PEV }\end{array}$ & $\begin{array}{l}\text { \% de votantes en } \\
\text { relación a inscritos } \\
\text { en registros } \\
\text { electorales }\end{array}$ \\
\hline $\mathbf{1 9 8 8}$ & 7.720 .840 & 7.435 .910 & 7.251 .94 & 96,3 & 93,92 & 97,52 \\
\hline
\end{tabular}

Fuente: ROJAS HERNÁNDEZ, Eduardo, Los jóvenes y el Plebiscito de 1988: Aproximación a las motivaciones de los jóvenes por participar del Plebiscito de 1988, 2006 2 .

De mejor o peor grado, confiando en la victoria del general Pinochet o temiendo que, si perdía, los resultados no se respetaran, con la primera votación hecha de manera no espuria desde el gobierno de la Unidad Popular y el golpe de Estado de 1973, la enorme mayoría de las y los mayores de dieciocho años se inscribió en los registros electorales y acudió a las urnas.

10. ROJAS HERNÁNDEZ, Eduardo, Los jóvenes y el Plebiscito de 1988: Aproximación a las motivaciones de los jóvenes por participar del Plebiscito de 1988, Informe para optar al grado de Licenciado en Historia, Departamento de Ciencias Históricas, Universidad de Chile, 2006. 


\section{III.EL MATRIMONIO MORGANÁTICO}

Como bien sabemos, la alternativa No triunfó en el plebiscito, el general Pinochet (aun de mala gana) aceptó los resultados y se convocaron elecciones presidenciales para 1989. Ese mismo año se dieron los últimos toques de cincel a una transición que terminaba. El 30 de julio de 1989 un nuevo plebiscito -mucho menos dramático y tenso que el ocurrido nueve meses antes- aprobó un paquete de reformas constitucionales que eliminó el autoritarismo más escandaloso de la Carta de 1980, pero no cambió sustancialmente su contenido: se derogó el artículo $8^{\circ}$, que declaraba ilegal ser marxista y la facultad presidencial de exiliar personas o de disolver la Cámara de Diputados, pero la democracia protegida y con los militares como garantes de la institucionalidad siguió intacta: los comandantes en jefe siguieron siendo inamovibles por el Poder Ejecutivo, el sistema de elecciones binominal se mantuvo y en términos prácticos y de la mayor relevancia, el general Pinochet continuó como comandante en jefe del Ejército y la institución de los senadores designados -donde él mismo esperaba estar desde 1998 en adelantetampoco se modificó.

Desde dicha perspectiva, lo que ocurrió en 1990 -el paso de la banda presidencial de un dictador a un presidente, las banderas con la frase "así me gusta Chile" que enarbolaron quienes fueron a celebrar el cambio de mando al Congreso Nacional en Valparaíso- fue un acto que ya pertenecía a lo que en este texto hemos denominado el proceso de instalación democrática a partir de una transición que ya había sido.

No es de extrañar, entonces, la confusión de los ciudadanos. Los sectores de derecha y pinochetistas, que quizás temieron hordas de izquierdistas furiosos en las calles, pudieron respirar: en realidad, el peor levantamiento social contra la dictadura ya había ocurrido y ya se había acabado, y los grupos armados aún activos se encontraron cada vez más aislados por partidos y movimientos que habían tomado otro camino, lo que influyó, por cierto, en su relativamente rápida neutralización durante la década de los ' 90 . No es de extrañar, tampoco, que dicha década nos haya dejado algunos de los ensayos más lúcidos y valiosos sobre el Chile de la segunda mitad del siglo XX, que son el fundamento teórico de cómo nos leemos hasta hoy: no se equivocaba Tomás Moulian cuando definía a ese Chile actual de los '90 a partir de la jaula de hierro weberiana, ni Alfredo JocelynHolt cuando hablaba de un país perplejo, que quizás había pasado por mucho en muy poco tiempo, o Martin Hopenhayn, que miraba más allá y ponía a Chile en el contexto global donde debía estar: un país donde se había negociado una democracia moderada y pactada con un gobierno autoritario, en un mundo donde casi de un día a otro cayeron los así llamados "socialismos reales" y los horizontes 
revolucionarios y de cambio social parecieron desaparecer en el triunfo generalizado del neoliberalismo ${ }^{11}$.

En la década de 1990 y mirándolo a veinte años de distancia, Chile quizás puede definirse como un país cansado, aliviado, molesto y confundido, y todo ello al mismo tiempo. Sería fácil decir, desde una perspectiva desencantada de izquierda, que "la dictadura ganó" y construyó una democracia a su medida; eso es cierto, pero mucho menos cierto para el pinochetismo, que de todas maneras tuvo que soportar las verdades incómodas de los informes Rettig y Valech, ver a los antiguos y despreciados "políticos" en el poder, o para esos mismos políticos y militantes concertacionistas que llegaron al poder, e incluso para los exiliados que pudieron regresar a su país. Como suele ocurrir en las situaciones donde no hay un corte radical con el pasado sino una adaptación de lo que ya existía, las derrotas y las victorias fueron relativas a y a cambio de. Nadie fue ni quedó particularmente feliz con los resultados y más que construir una transición, la gran interrogante de los ' 90 fue cómo medrar y qué hacer en esa nueva democracia, es decir, en esa casa que ya estaba construida y que había que habitar.

Volviendo a la pregunta inicial de este texto (y un poco para cerrar lo que no puede cerrarse, que es la historia como proceso), creo que la transición a la democracia en Chile fue un tiempo crispado, de ensayo y error, de angustia y cesiones que comenzó con el estallido de una crisis económica y terminó con un compromiso que buscaba neutralizar lo peor, siendo eso, lo peor, que la dictadura se auto-regenerara como una hidra o -imagen más local- como la cola de las lagartijas. Esa transición estuvo marcada por las profundas reformas que ya había hecho la dictadura en sus diez años en el poder -obra que la oposición no fue capaz de derribar- y también por la memoria del violento fin de la Unidad Popular y el golpe de Estado: si hubo algo indeseado para la mayoría de los chilenos, si había una amenaza que se quería evitar, era una nueva Moneda en llamas, era más conflicto, más inseguridad, más represión y más muerte. Ante el peligro de un general Pinochet que ya se las había arreglado para estar más de una década en el poder, sortear una crisis económica y seguir teniendo apoyo -en el plebiscito de 1988, un 44\% de los ciudadanos votó por él-, esa democracia negociada y, a fin de cuentas, sin sangre de por medio, pareció la mejor opción.

11. Ver MOULIAN, Tomás, Chile actual. Anatomía de un mito, Santiago, LOM Ediciones, 1996; JOCELYN-HOLT, Alfredo, El Chile perplejo. Del avanzar sin transar al transar sin parar, Santiago, Editorial Planeta Ariel, 1998; HOPENHAYN, Martin, Ni apocalípticos ni integrados: aventuras de la modernidad en América Latina, Fondo de Cultura Económica, 1994. 


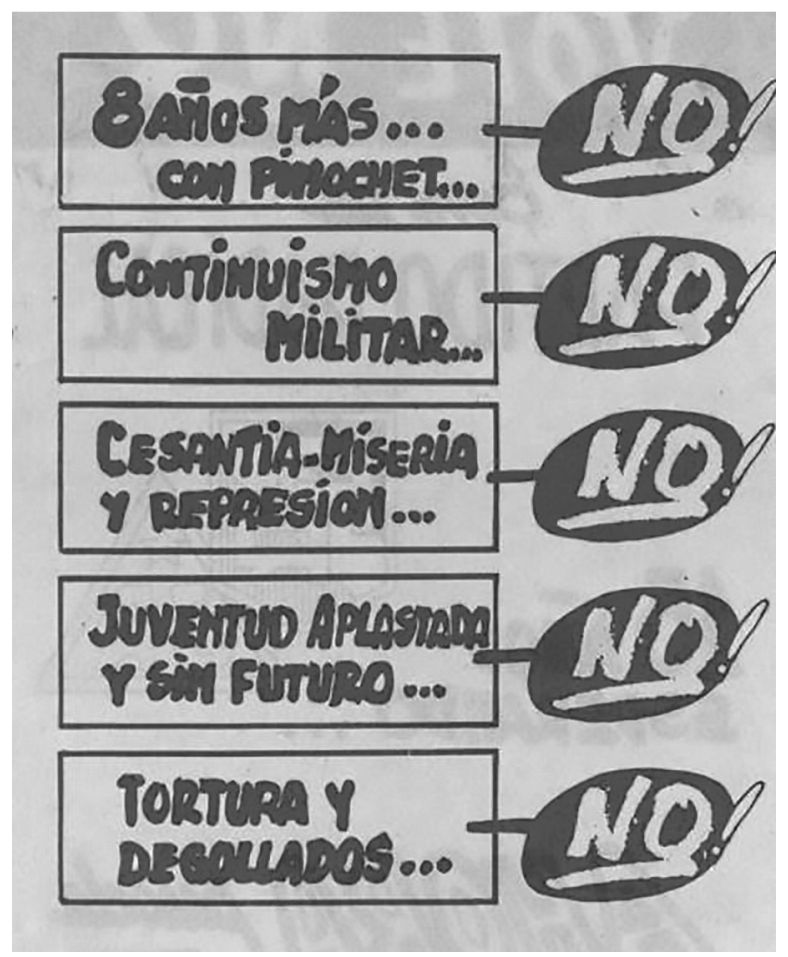

Fuente: panfleto callejero de la campaña del No, en ROJAS HERNÁNDEZ, Eduardo, Los jóvenes y el Plebiscito de 1988, 2006.

De allí la importancia de revisitar y de entender esa década de 1980. Mirada en perspectiva, se inició con la construcción de una estructura estatal vigente hasta hoy -entre 1980 y 1982 se aprobó la municipalización de los liceos y escuelas y la privatización de la seguridad social y de salud, y se volvió norma constitucional el Estado subsidiario, entre otras medidas- y continuó con la negociación múltiple para adaptar ese modelo a una estructura democrática clásica, es decir, con tres poderes de Estado, Fuerzas Armadas no deliberantes y elección periódica de autoridades. Se buscó sortear, además, el peligro de un contragolpe de la derecha o de una sublevación popular desde la izquierda.

Fue, entonces, una suerte de matrimonio morganático, donde la oposición de centro-izquierda ganó un lugar en el poder a costa de ceder sus esperanzas de cambio significativo, y una dictadura de derecha, nada contenta, pero adaptándose, aceptó la alianza. Somos los hijos y las hijas de esa unión desigual, es decir, somos los descendientes sin derechos sobre el poder, los bienes o los títulos del cónyuge privilegiado y su familia. Si en algún momento seremos capaces de romper ese acuerdo de fondo y reclamar lo que nos corresponde, ya son preguntas de este siglo, no del anterior. 